Public Utility Economics 


\section{Public Utility Economics}

Michael A. Crew and Paul R. Kleindorfer 
() Michael A. Crew and Paul R. Kleindorfer 1979

Softcover reprint of the hardcover 1st edition 1979

All rights reserved. No part of this publication may be reproduced or transmitted, in any form or by any means, without permission.

First published 1979 by

THE MACMILLAN PRESS LTD

London and Basingstoke

Associated companies in Delhi Dublin

Hong Kong Johannesburg Lagos Melbourne

New York Singapore and Tokyo

Typeset by

Reproduction Drawings Ltd, Sutton, Surrey

\section{British Library Cataloguing in Publication Data}

Crew, Michael Anthony

Public utility economics.

1. Public utilities 2. Economics

I. Title II. Kleindorfer, Paul R

338.4' $7^{\prime} 3636 \quad$ HD2763

ISBN 978-1-349-03265-5 ISBN 978-1-349-03263-1 (eBook)

DOI 10.1007/978-1-349-03263-1

This book is sold subject to the standard conditions of the Net Book Agreement. 


\section{Contents}

Preface and Acknowledgements vii

Part One Setting the Scene 1

1 Introduction 3

2 Welfare Economic Foundations 6

Part Two A General and Comprehensive Analysis of PEAK-LOAd Pricing

3 Introduction to the Theory of Peak-load Pricing 25

4 Peak-load Pricing Models under Certainty 36

5 Stochastic Models of Peak-load Pricing 66

6 Some Numerical Illustrations 99

7 Dynamic Analysis of Peak-load Pricing 108

Part Three Public Utility Regulation 117

8 Public Utility Regulation or Public Ownership 119

9 Some Theoretical Considerations of Regulation 129

Part Four Policy ImPlications for Electricity SuPPLy 157

10 Electricity Supply 159

11 Peak-load Pricing and Energy Conservation 179

12 Concluding Remarks 194

Mathematical Appendix 201

Solution and Hints to Selected Problems 209

Notes $\quad 215$

References 231

Index 243 


\section{Preface and Acknowledgements}

The growth in public utilities and public enterprise over the last thirty years has prompted an increasing interest by economists, management scientists, administrators and politicians in the problems of public utility economics. This book aims to provide an analytical basis for those who wish to study, manage or prescribe policies for public utilities. Its approach is primarily theoretical and research-orientated, with applications provided for purposes of illustration.

The level of the analysis is within the capabilities of graduate students who have completed courses in microeconomic theory, and those who have done the now commonplace courses in calculus, linear algebra and optimisation. However, in an attempt to be comprehensive and rigorous, a number of appendixes have been provided which furnish detailed proofs of certain propositions and which review some of the more specialised techniques used. In addition numerical exercises, some with fully worked answers, are provided. These, it is hoped, will prove valuable to serious students in assessing their grasp of the theory.

The idea of the book arose out of a long research collaboration which began in 1969 at Carnegie-Mellon University. Since then, except for 1977 , the collaboration has taken place mostly at an average distance of 3000 miles, with occasional trips by both authors across the Atlantic. All of what is contained here, with the exception of Chapter 7, arises out of our joint published work. On Chapter 7 however, we collaborated with Hong-Chang Chang, a Ph.D. candidate of the University of Pennsylvania. We are pleased to acknowledge his participation as a co-author of Chapter 7 and his comments on the rest of the text.

We are especially grateful to Roger Sherman of the University of Virginia who acted as reader for the publisher. His comments made us think carefully about our ideas and strive for clarity of exposition, and went far beyond the normal duties of reader with the result that we were able to improve and extend our original manuscript in a number of important respects.

We would also like to acknowledge comments and discussion with many colleagues over the years that gave us insights into our work, 
viii Preface and Acknowledgements

especially Walter Goldberg, Howard Kunreuther, Bridger Mitchell, Fred Sudit and Sidney Weintraub, who are not to be blamed for any remaining errors, however.

We would like to thank Shelley Bauer, Naomi Coyle, Lenore Rutz and Diane Weinstock for typing assistance.

Finally, we are most grateful to our wives for their support and uncommon patience in the ten-year wait for the fruits of this endeavour.

M. A. C.

P. R. K. 